\title{
Kualitas Hidup Family Caregiver Pasien Orang dengan Skizofrenia
} (ODS)

\author{
Ligina Ayudia', Ahmad Gimmy Prathama Siswadi' ${ }^{2}$,Fredrick Dermawan Purba ${ }^{3}$ \\ 1,2,3Fakultas Psikologi Universitas Padjadjaran; Jl. Raya Bandung Sumedang KM 21, Jawa barat, \\ Indonesia, (022) 779-4126 / 7794127. Faksimile: (022) 87920376 \\ e-mail: *1ligina18001@unpad.ac.id, 2ahmad.gimmy@unpad.ac.id,3fredrickpurba@unpad.ac.id
}

Article History:

Received

$07-11-2020$

Review

$07-12-2020$

Revised

$08-12-2020$

Accepted

$09-12-2020$

Published

$10-12-2020$

Abstract. The ODS family caregivers are prone to problems so overall quality of life is reduced. Assessing quality of life can help family caregiver appropriately. This study describes quality of life of ODS caregiver family and knows demographic aspects that affect quality of life. . Using a quantitative descriptive method with convenience sampling with a sample of 100 ODS caregiver families at RSUD Soreang. Measuring instrument used by Adult Carers Quality of Life consists of 8 dimensions ( 40 items). Processed using descriptive statistics, correlation test, test the difference between the two means. The results showed that quality of life of ODS caregiver family was moderate the high category is shown the caring choice dimension. Based on the data, there is a relationship between variable quality of life and age and there is a significant difference in quality of life of family caregivers based on education and length of care.

Keywords: (Family Caregiver, Quality of Life, People with Schizophrenia (ODS)

\begin{abstract}
Abstrak. Family caregiver ODS rentan terhadap masalah sehingga secara keseluruhan kualitas hidup berkurang. Menilai kualitas hidup dapat membantu family caregiver secara tepat. Penelitian ini menggambarkan kualitas hidup family caregiver ODS dan mengetahui aspek demografi yang mempengaruhi kualitas hidupnya. Menggunakan metode deskriptif kuantitatif dengan convenience sampling dengan sampel 100 family caregiver ODS di RSUD Soreang. Alat ukur yang digunakan Adult Carers Quality of Life terdiri dari 8 dimensi (40 item). Diolah menggunakan statistik deskriptif, uji korelasi, uji perbedaan dua rata-rata. Hasil penelitian menunjukkan kualitas hidup family caregiver ODS tergolong sedang. kategori tinggi ditunjukkan dimensi caring choice. Kategori sedang ditunjukkan oleh dimensi support for caring, caring stress, money matters, personal growth, sense of value, careers satisfaction dan ability to care. Berdasarkan data terdapat hubungan antara variabel kualitas hidup dengan usia dan terdapat perbedaan signifikan pada kualitas hidup family caregiver berdasarkan pendidikan \& lama merawat.
\end{abstract}

Kata kunci: Family Caregiver, Kualitas Hidup, Orang dengan Skizofrenia(ODS)

\section{Pendahuluan}

Peristiwa kehidupan yang penuh tekanan seperti kehilangan orang yang dicintai, putusnya hubungan sosial, pengangguran, masalah dalam pernikahan, kesulitan ekonomi, tekanan di pekerjaan dan diskriminasi meningkatkan risiko penderita gangguan jiwa (Sulistyorini, 2013). Salah satu gangguan jiwa yang dikategorikan berat adalah skizofrenia. Skizofrenia menurut Diagnostic Statistical Manual-5 (DSM-5) didefinisikan sebagai kelainan dalam satu atau lebih dari lima domain berikut: delusi, halusinasi, tidak terorganisir dalam berpikir dan berbicara, perilaku motorik yang sangat tidak teratur atau tidak normal (termasuk katatonia), dan gejala negatif (American Psychiatric Association, 2013).

Terdapat 21 juta orang di dunia yang menderita skizofrenia: orang dengan skizofrenia/ODS (James et al., 2018). Sementara di Indonesia prevalensinya terus meningkat 
dari 1,7 penderita setiap 1000 orang di tahun 2013 menjadi 7 penderita setiap 1000 orang di tahun 2018 (Kementerian Kesehatan RI Badan Penelitian dan Pengembangan, 2018). Salah satu daerah di Indonesia yang mengalami peningkatan individu dengan gangguan jiwa ialah Jawa Barat, dimana terjadi peningkatan dari 1,5 penderita setiap 1000 orang di tahun 2013 menjadi 5 penderita setiap 1000 orang di tahun 2018 (Kementerian Kesehatan RI Badan Penelitian dan Pengembangan, 2018).

RSUD Soreang adalah rumah sakit pemerintah kabupaten Bandung, dengan jumlah pasien poliklinik psikiatri terbanyak di wilayah Bandung. Dalam 3 tahun terakhir terjadi peningkatan pada jumlah ODS sebanyak 30\% (Petugas rekap medis, 2009). Menurut (Dohrenwend, 2000) keadaan stres seperti tinggal di dalam kota lingkungan yang miskin dan memiliki pekerjaan berstatus rendah atau menganggur menyebabkan individu mengalami skizofrenia. Hal ini serupa dengan pernyataan (van Os \& Kapur, 2009) bahwa resiko skizofrenia meningkat secara linear dengan lingkungan urban di mana anak-anak tumbuh.

ODS mengalami kesulitan dalam menjalankan kehidupannya sehari-hari, mengalami keterbatasan dalam beraktivitas, ketika kambuh berperilaku menyimpang dan membutuhkan bantuan hampir di seluruh aktivitasnya sehingga di perlukan orang lain yang dapat memenuhi kebutuhannya (Katschnig, 2000). Mereka yang merawat ODS, disebut sebagai caregiver ODS, sering kali adalah anggota keluarga yang tidak terlatih dalam kesehatan mental. Individuindividu ini memberikan dukungan penting bagi orang yang mereka cintai, tetapi dalam melakukan hal itu mereka rentan terhadap depresi, stres, masalah kesehatan fisik, beban stigma, dan berkurangnya kehidupan sosial. Kualitas hidup secara keseluruhan menjadi parah (Bright Quest, 2019).

Menilai kualitas hidup menjadi penting karena semakin dituntutnya intervensi untuk membantu family caregiver dapat dievaluasi secara memadai. Family caregiver yang sejahtera akan mendukung efektivitas intervensi pada ODS, karena family caregiver dianggap sebagai kompenen berharga dalam integrasi pasien yang mana merupakan pelaku utama rehabilitasi bagi anggota keluarga yang sakit (Caqueo-Urízar et al., 2011). Mengamati adanya perubahan yang terjadi dalam menjalankan aktivitas sehari-hari yang ditampilkan oleh family caregiver ODS dirasa perlu untuk meneliti bagaimana peran dan tanggung jawab merawat ODS yang kemudian mempengaruhi seluruh aspek hidup seorang family caregiver, khususnya kualitas hidupnya.

Pencarian pada beberapa database, seperti PubMed dan Google Scholar tidak menemukan penelitian sebelumnya di Indonesia yang menggambarkan kualitas hidup berdasarkan alat ukur khusus untuk caregiver. Alat ukur yang tidak dirancang khusus untuk caregiver akan gagal untuk menilai domain tertentu yang penting bagi caregiver (Becker, 2011). 
Karenanya, tujuan penelitian ini adalah mendapatkan gambaran kualitas hidup family caregiver ODS pada caregiver pasien ODS menggunakan alat ukur khusus caregiver yakni Adult Carers Quality of Life (AC-Qol) dan mengetahui aspek-aspek demografi yang mempengaruhi kualitas hidup family caregiver .

\section{Metode}

Rancangan penelitian ini adalah desain potong lintang (cross sectional) dengan metode survei yang dilakukan di RSUD Soreang. Pengambilan data menggunakan metode convenience sampling dilakukan pada 100 family caregiver ODS yang terpilih memenuhi kriteria inklusi selama periode bulan April-Juli 2020. Kriteria inklusi meliputi (1) pengasuh utama (nonprofesional dan tidak dibayar) dari pasien yang terdokumentasi dalam rekam medis yang memiliki diagnosis skizofrenia di poli psikiatri RSUD Soreang (2) orang dewasa berusia 18 tahun atau lebih (3) tidak memiliki cacat kognitif atau gangguan bahasa yang dinilai dari laporan partisipan dan observasi peneliti (4) bersedia untuk berpartisipasi dalam penelitian. Kriteria eksklusi meliputi (1) memiliki cacat kognitif atau gangguan bahasa yang dinilai dari laporan partisipan dan observasi peneliti dan (2) tidak bersedia berpartisipasi dalam penelitian.

Sebelum memulai penelitian, persetujuan etik diperoleh dari komite etik kedokteran Universitas Padjadjaran dengan nomor 169/UN6.KEP/EC/2020 dan semua responden mendatangani informed consent untuk berpartisipasi dalam studi. Data dikumpulkan menggunakan kuesioner secara tatap muka yang dilakukan oleh peneliti dengan durasi waktu 15 menit di setiap responden. Peneliti mengenalkan diri kepada responden sebelum meminta pengisian kuesioner dan dengan jelas mengungkapkan tujuan penelitian. Untuk memastikan privasi, pengambilan data dilakukan di ruangan poli psikiatri yang hanya terdiri oleh peneliti dan responden.

Instrumen penelitian yang digunakan kuesioner Adult Carer Quality of Life (AC-QoL), terdiri dari 8 dimensi yakni: (i) support for caring yakni sejauh mana family caregiver yang merawat anggota keluarga ODS merasa bahwa mereka merasa berharga, dipahami, dapat berbagi informasi, merasa dihormati dan mendapat dukungan satu sama lain baik oleh anggota keluarga lainya maupun oleh profesional, (ii) caring choice yakni sejauh mana family caregiver yang merawat anggota keluarga ODS merasa bahwa mereka memiliki kendali atas kehidupan mereka sendiri, dan dapat memilih melakukan aktivitas lain di luar caring, (iii) caring stress yakni tekanan mental fisik dari caring, seperti kelelahan dan depresi, (iv) money matters yakni bagaimana family caregiver yang merawat anggota keluarga ODS mengatasi situasi keuangan mereka, (v) personal growth yakni seberapa besar perasaan family caregiver yang merawat anggota keluarga ODS merasa dirinya tumbuh dan berkembang, dan pengalaman positif yang 
didapat dari keadaan sebagai family caregiver, (vi) sense of value yakni sejauh mana family caregiver yang merawat anggota keluarga ODS merasa dihargai dan dihormati dan adanya hubungan positif antara dirinya dengan orang yang mereka rawat, (vii) ability to care yakni sejauh mana family caregiver yang merawat anggota keluarga ODS bisa memberikan perawatan terhadap ODS, bagaimana mereka mengatasi peran, dan bagaimana perasaan mereka tentang kemampuan mereka terhadap caring dan (viii) carer satisfaction yakni sejauh mana family caregiver yang merawat anggota keluarga ODS puas dengan kehidupan dan peran sebagai pengasuh, dan bagaimana perasaan mereka sebagai pengasuh. Dengan masing-masing dimensi terdiri dari 5 item dengan jumlah keseluruhan 40 item yang dirancang untuk menilai kualitas hidup dari caregiver dewasa. Mayoritas item AC-QoL diberi skor dari 0 (tidak pernah) hingga 3 (selalu), tetapi item 6-16, 19, 37 dan 38 diberi skor secara terbalik. Skor total yang dimungkinkan adalah 120, dengan skor yang lebih tinggi menunjukkan kualitas hidup yang lebih baik. AC-QoL terbukti sebagai alat ukur yang dapat diandalkan dengan skor Cronbach's Alpha 0,83 sampai 0,93 (Chien, Chan, \& Morrissey, 2007; Joseph \& Becker, 2012;(Brand, Brand, Barry, \& Gallagher, 2014).

Data yang dikumpulkan ditabulasi dan dilakukan analisis menggunakan Software Statistical Package for the Social Science (SPSS) versi 18, dengan langkah-langkah: (1) menggunakan statistik deskriptif untuk menggambarkan responden terkait variabel kualitas hidup family caregiver dan data demografisnya, (2) melakukan uji normalitas untuk menggambarkan persebaran data dari variabel kualitas hidup family caregiver dan data demografis, dengan uji Kolmogorov-Smirnov, (3) melakukan uji beda untuk menggambarkan pada kelompok variabel demografis kecuali usia. Pada penelitian ini, karena data tidak berdistribusi normal, peneliti menggunakan uji beda dengan Mann Whitney dan Kruskall Wallis, (4) melakukan uji korelasi untuk data demografi khusus usia dengan kualitas hidup family caregiver. Pada penelitian ini menggunakan uji korelasi Pearson antara kualitas hidup family caregiver dengan usia responden.

\section{Hasil}

Sebanyak 100 orang yang tercatat sebagai responden penelitian yang mengisi kuesioner AC-QoL memiliki karakteristik demografis yang ditampilkan dalam tabel 1. Dapat terlihat bahwa mayoritas family caregiver ODS berusia 51-60 tahun (36\%),perempuan (62\%) dengan 85\% family caregiver sudah menikah, status hubungan dengan keluarga yang dirawat adalah anak (63\%). Mayoritas responden bersuku Sunda (94\%), berpendidikan SD (51\%) dan tidak bekerja (52\%). Merekaumumnya merawat keluarga dengan diagnosa skizofrenia yang tidak tergolongkan (37\%). Lama merawat mayoritas rata-rata pada rentang 0-5 tahun berkisar 42\% dengan durasi lama merawat ODS rata-rata 2,26 tahun dan Standard Deviasi (SD)=1,244. 
Philanthropy Journal of Psychology

Volume 4 Nomor 2 (2020), 128-142

ISSN 2580-6076 (Print), ISSN 2580-8532 (Online)

Tabel 1. Karakteristik Demografis Responden Penelitian

\begin{tabular}{|c|c|c|}
\hline Variabel & Kategori & $\mathrm{N}(\%)$ \\
\hline Usia (Tahun) & $\begin{array}{l}<40 \\
41-50 \\
\mathbf{5 1 - 6 0} \\
61-70\end{array}$ & $\begin{array}{l}14(14,0) \\
31(31,0) \\
\mathbf{3 6}(36,0) \\
19(19,0)\end{array}$ \\
\hline Jenis kelamin & $\begin{array}{l}\text { Laki-laki } \\
\text { Perempuan }\end{array}$ & $\begin{array}{l}38(38,0) \\
62(62,0)\end{array}$ \\
\hline Status pernikahan & $\begin{array}{l}\text { Menikah } \\
\text { Single/Bercerai/Duda/janda }\end{array}$ & $\begin{array}{l}\mathbf{8 5}(\mathbf{8 5}, \mathbf{0}) \\
15(15,0)\end{array}$ \\
\hline Hubungan & $\begin{array}{l}\text { Anak } \\
\text { Pasangan } \\
\text { Orang tua } \\
\text { Lainnya }\end{array}$ & $\begin{array}{l}\mathbf{6 3 ( 6 3 , 0 )} \\
9(9,0) \\
4(4,0) \\
24(24,0)\end{array}$ \\
\hline Suku & $\begin{array}{l}\text { Bali } \\
\text { Jawa } \\
\text { Sunda }\end{array}$ & $\begin{array}{l}1(1,0) \\
5(5,0) \\
\mathbf{9 4}(\mathbf{9 4 , 0 )}\end{array}$ \\
\hline Pendidikan & $\begin{array}{l}\text { SD } \\
\text { SMP } \\
\text { SMA } \\
\text { D3 } \\
\text { S1 } \\
\end{array}$ & $\begin{array}{l}\mathbf{5 1}(\mathbf{5 1 , 0 )} \\
20(20,0) \\
22(22,0) \\
2(2,0) \\
4(4,0)\end{array}$ \\
\hline Pekerjaan & $\begin{array}{l}\text { Buruh } \\
\text { Pedagang } \\
\text { Tidak bekerja } \\
\text { Lainnya }\end{array}$ & $\begin{array}{l}20(20,0) \\
10(10,0) \\
52(52,0 \\
18(18,0)\end{array}$ \\
\hline Diagnosis ODS & $\begin{array}{l}\text { Skizofrenia paranoid } \\
\text { Skizofrenia hebefrenik } \\
\text { Depresi pasca-skizofrenia } \\
\text { Skizofrenia residual } \\
\text { Skizofrenia yang tidak } \\
\text { tergolongkan }\end{array}$ & $\begin{array}{l}19(19,0) \\
27(27,0) \\
9(9,0) \\
8(8,0) \\
\mathbf{3 7 ( 3 7 , 0 )}\end{array}$ \\
\hline Lama merawat & $\begin{array}{l}\text { 0-5 Thn } \\
6-10 \text { Thn } \\
11-15 \text { Thn } \\
>15 \text { Thn } \\
\end{array}$ & $\begin{array}{l}\mathbf{4 2 ( 4 2 , 0 )} \\
15(15,0) \\
18(18,0) \\
25(25,0)\end{array}$ \\
\hline Mean & 2,25 Thn & \\
\hline Standar deviasi & 1,244 & \\
\hline
\end{tabular}

Keterangan:

Skor yang ditebalkan adalah kelompok porsi yang paling besar.

Berdasarkan Tabel 2. dapat dikatakan bahwa 61\% mayoritas family caregiver ODS memiliki kualitas hidup sedang.

Tabel 2. Kualitas hidup family caregiver ODS secara keseluruhan

\begin{tabular}{lll}
\hline Kualitas Hidup & Frekuensi & $\%$ \\
\hline Rendah & 16 & 16.0 \\
Sedang & $\mathbf{6 1}$ & $\mathbf{6 1 . 0}$ \\
Tinggi & 23 & 23.0 \\
\hline
\end{tabular}


Keterangan:

Skor yang ditebalkan adalah kelompok porsi yang paling besar.

Berdasarkan tabel 3. Mayoritas family caregiver tergolong sedang untuk dimensi support for caring(41\%), money matter (51\%), personal growth (40\%), sense of value (40\%), carer satisfaction (53\%). Kualitas hidup rendah family caregiver ODS berada pada dimensi ability to care yakni sebanyak 48\% dan kualitas hidup tinggi family caregiver ODS berada pada dimensi caring choice.

Tabel 3. Kategorisasi Dimensi Kualitas Hidup, Mean \& SD AC-QOL

\begin{tabular}{|c|c|c|c|c|}
\hline Dimensi & Kategori & $\mathbf{N}(\%)$ & Mean & SD \\
\hline \multirow[t]{3}{*}{ Support for caring } & Rendah & $36(36.0)$ & 7,37 & 3,81 \\
\hline & Sedang & $41(41.0)$ & & \\
\hline & Tinggi & $23(23.0)$ & & \\
\hline \multirow[t]{3}{*}{ Caring choice } & Rendah & $10(10.0)$ & 11,30 & $\mathbf{3 , 8 8}$ \\
\hline & Sedang & $22(22.0)$ & & \\
\hline & Tinggi & $68(68.0)$ & & \\
\hline \multirow[t]{3}{*}{ Caring stress } & Rendah & $24(24.0)$ & 9,56 & 4,86 \\
\hline & Sedang & $25(25.0)$ & & \\
\hline & Tinggi & $51(51.0)$ & & \\
\hline \multirow[t]{3}{*}{ Money matters } & Rendah & $37(37.0)$ & 6,50 & 3,32 \\
\hline & Sedang & $51(51.0)$ & & \\
\hline & Tinggi & $12(12.0)$ & & \\
\hline \multirow[t]{3}{*}{ Personal Growth } & Rendah & $39(39.0)$ & 6,90 & 4,05 \\
\hline & Sedang & $40(40.0)$ & & \\
\hline & Tinggi & $21(21.0)$ & & \\
\hline \multirow[t]{3}{*}{ Sense of value } & Rendah & $35(35.0)$ & 7,46 & 3,98 \\
\hline & Sedang & $40(40.0)$ & & \\
\hline & Tinggi & $25(25.0)$ & & \\
\hline \multirow[t]{3}{*}{ Ability to care } & Rendah & $48(48.0)$ & 7,28 & 3,85 \\
\hline & Sedang & $29(29.0)$ & & \\
\hline & Tinggi & $23(23.0)$ & & \\
\hline \multirow[t]{3}{*}{ Carer Satisfaction } & Rendah & $4(4.0)$ & 9,92 & 2,83 \\
\hline & Sedang & $53(53.0)$ & & \\
\hline & Tinggi & $43(43.0)$ & & \\
\hline
\end{tabular}

Keterangan:

Skor yang ditebalkan adalah kelompok porsi yang paling besar.

Berdasarkan tabel 4. Rata -rata family caregiver yang tergolong memiliki kualitas hidup rendah memiliki dimensi rendah pada dimensi support for caring, caring stress, money maters, personal growth, sense of value ability to care career satisfaction dan dimensi sedang pada caring choice. Pada family caregiver yang tergolong memiliki kualitas hidup sedang terdiri dari dimensi sedang di seluruh dimensi nya dan family caregiver yang tergolong memiliki kualitas hidup tinggi terdiri dari dimensi sedang pada support for caring dan money matters dan tinggi pada dimensi caring choice, caring stress, personal growth, sense of value ability to care career satisfaction 
Tabel 4. Profile Kualitas Hidup family caregiver ODS

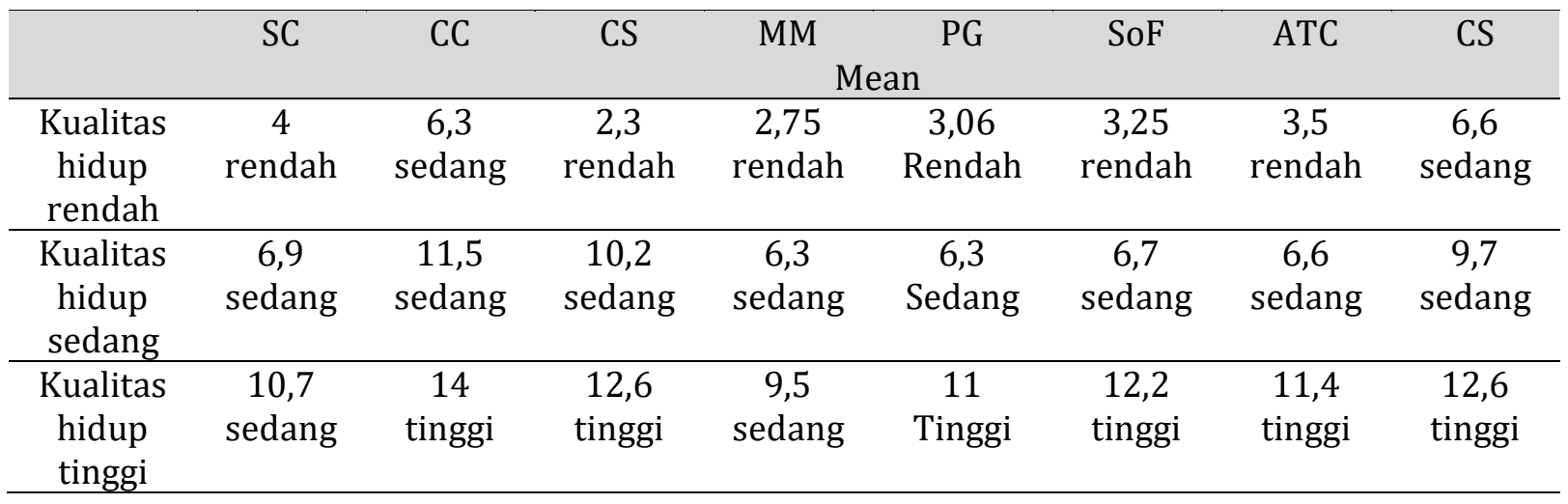

Untuk data demografi, terlihat dalam tabel 5. Hasil Uji Korelasi dan Uji Beda Data Demografi dengan Dimensi AC-QoL bahwa besaran nilai korelasi antara usia antara responden adalah $r=-0,390$ dengan $\mathrm{P}$-value 0,000 artinya usia memiliki korelasi yang signifikan dengan kualitas hidup. Nilai koefisien bernilai negatif artinya usia memiliki korelasi yang signifikan dengan kualitas hidup. Nilai koefisien bernilai negatif bermakna semakin tua usia family caregiver mengakibatkan semakin rendahnya kualitas hidup atau sebaliknya. Selanjutnya ketika dilakukan uji beda pada data demografi menunjukan bahwa terdapat perbedaan yang signifikan terhadap kategori pendidikan dan lamanya merawat. 
Philanthropy Journal of Psychology

Volume 4 Nomor 2 (2020), 128-142

ISSN 2580-6076 (Print), ISSN 2580-8532 (Online)

Tabel 5 Hasil Uji Korelasi dan Uji Beda Data Demografi dengan Dimensi AC-QoL

\begin{tabular}{|c|c|c|c|c|c|c|c|c|c|c|c|c|c|c|c|c|c|c|c|}
\hline \multicolumn{2}{|c|}{ Data demografi } & \multicolumn{2}{|c|}{$\begin{array}{l}\text { Dimensi (support } \\
\text { for caring) }\end{array}$} & \multicolumn{2}{|c|}{$\begin{array}{c}\text { Dimensi } 2 \\
\text { (Caring Choice) }\end{array}$} & \multicolumn{2}{|c|}{$\begin{array}{c}\text { Dimensi } 3 \\
\text { (Caring Stress) }\end{array}$} & \multicolumn{2}{|c|}{$\begin{array}{c}\text { Dimensi } 4 \\
\text { (Money Matters) }\end{array}$} & \multicolumn{2}{|c|}{$\begin{array}{c}\text { Dimensi } 5 \\
\text { (Personal Growth) }\end{array}$} & \multicolumn{2}{|c|}{$\begin{array}{l}\text { Dimensi } 6 \\
\text { (Sense of } \\
\text { Value) }\end{array}$} & \multicolumn{2}{|c|}{$\begin{array}{c}\text { Dimensi } 7 \\
\text { (Ability to care ) }\end{array}$} & \multicolumn{2}{|c|}{$\begin{array}{c}\text { Dimensi } 8 \\
\text { (Career } \\
\text { satisfaction ) }\end{array}$} & \multicolumn{2}{|c|}{ Total } \\
\hline \multicolumn{2}{|l|}{ Usia } & \multicolumn{2}{|c|}{$\begin{array}{l}r=-0,260 * * \\
P=0,009\end{array}$} & \multicolumn{2}{|c|}{$\begin{array}{l}r=-0,249 * \\
P=0,012\end{array}$} & \multicolumn{2}{|c|}{$\begin{array}{l}\mathbf{r}=-\mathbf{0}, 391 * * \\
\mathbf{P}=\mathbf{0 , 0 0 0}\end{array}$} & \multicolumn{2}{|c|}{$\begin{array}{l}\mathbf{r}=-\mathbf{0}, 374 * * \\
\mathbf{P}=\mathbf{0 , 0 0 0}\end{array}$} & \multicolumn{2}{|c|}{$\begin{array}{l}r=-0,226 * \\
P+0,024\end{array}$} & \multicolumn{2}{|c|}{$\begin{array}{l}\mathbf{r}=-\mathbf{0 , 3 0 8} * * \\
\mathbf{P}=0,002\end{array}$} & \multicolumn{2}{|c|}{$\begin{array}{l}r=-0,203 * \\
P=0,043\end{array}$} & \multicolumn{2}{|c|}{$\begin{array}{l}\mathbf{r}=\mathbf{- 0 , 2 0 7} * \\
\mathbf{P}=\mathbf{0 , 0 3 8}\end{array}$} & \multicolumn{2}{|c|}{$\begin{array}{l}\mathbf{r}=-\mathbf{0 , 3 9 0} * * \\
\mathbf{P}=\mathbf{0 , 0 0 0}\end{array}$} \\
\hline Data demo & & Mean & Sig & Mean & Sig & Mean & Sig & Mean & Sig & Mean & Sig & Mean & Sig & Mean & Sig & Mean & Sig & Mean & Sig \\
\hline JK & $\begin{array}{l}\text { Laki-laki } \\
\text { Perempuan }\end{array}$ & $\begin{array}{l}55,43 \\
47,48\end{array}$ & 0,181 & $\begin{array}{l}50,76 \\
50,34\end{array}$ & 0,943 & $\begin{array}{l}52,12 \\
49,51\end{array}$ & 0,661 & $\begin{array}{l}52,83 \\
49,07\end{array}$ & 0,527 & $\begin{array}{l}52,32 \\
49,39\end{array}$ & 0,623 & $\begin{array}{l}56,64 \\
46,73\end{array}$ & $\begin{array}{l}0,09 \\
6\end{array}$ & $\begin{array}{l}52,09 \\
49,52\end{array}$ & 0,664 & $\begin{array}{l}52,09 \\
46,98\end{array}$ & 0,118 & $\begin{array}{l}53,86 \\
48,44\end{array}$ & 0,365 \\
\hline $\begin{array}{l}\text { Pendidika } \\
\mathrm{n}\end{array}$ & $\begin{array}{l}\text { SD } \\
\text { SMP } \\
\text { SMA } \\
\text { D4/S1 } \\
\end{array}$ & $\begin{array}{l}43,73 \\
56,58 \\
57,82 \\
59,50 \\
\end{array}$ & 0,119 & $\begin{array}{l}43,33 \\
55,58 \\
59,73 \\
59,21 \\
\end{array}$ & 0,083 & $\begin{array}{l}40,37 \\
57,95 \\
65,34 \\
56,36 \\
\end{array}$ & $\begin{array}{l}\mathbf{0 , 0 0 5} \\
*\end{array}$ & $\begin{array}{l}37,89 \\
\\
53,18 \\
71,68 \\
68,14 \\
\end{array}$ & $\begin{array}{l}\mathbf{0 , 0 0 0} \\
*\end{array}$ & $\begin{array}{l}42,20 \\
57,60 \\
59,39 \\
62,79 \\
\end{array}$ & 0,312 & $\begin{array}{l}42,46 \\
53,85 \\
61,70 \\
64,29 \\
\end{array}$ & $\begin{array}{l}0,10 \\
8\end{array}$ & $\begin{array}{l}4,76 \\
50,90 \\
63,18 \\
51,29 \\
\end{array}$ & 0,200 & $\begin{array}{l}43,85 \\
\\
57,65 \\
57,52 \\
56,43 \\
\end{array}$ & $\begin{array}{l}\mathbf{0 , 0 6 1} \\
*\end{array}$ & $\begin{array}{l}39,05 \\
57,00 \\
67,16 \\
63,00 \\
\end{array}$ & 0,008* \\
\hline Pekerjaan & $\begin{array}{l}\text { Tidak bekerja } \\
\text { Buruh } \\
\text { Pedagang } \\
\text { Lainnya }\end{array}$ & $\begin{array}{l}52,61 \\
53,90 \\
38,55 \\
48,37\end{array}$ & 0,499 & $\begin{array}{l}52,25 \\
47,74 \\
50,55 \\
49,50\end{array}$ & 0,941 & $\begin{array}{l}50,98 \\
49,29 \\
42,85 \\
53,98\end{array}$ & 0,780 & $\begin{array}{l}53,05 \\
45,67 \\
56,15 \\
47,35\end{array}$ & 0,657 & $\begin{array}{l}50,49 \\
48,74 \\
62,20 \\
47,04\end{array}$ & 0,564 & $\begin{array}{l}46,15 \\
47,69 \\
50,05 \\
61,96\end{array}$ & $\begin{array}{l}0,18 \\
3\end{array}$ & $\begin{array}{l}48,48 \\
52,02 \\
50,00 \\
53,37\end{array}$ & 0,914 & $\begin{array}{l}50,64 \\
49,69 \\
56,10 \\
48,52\end{array}$ & 0,918 & $\begin{array}{l}50,54 \\
48,33 \\
48,80 \\
53,13\end{array}$ & 0,952 \\
\hline Diagnosa & $\begin{array}{l}\text { F. } 20.0 \\
\text { F. } 20.1 \\
\text { F. } 20.4 \\
\text { F. } 20.5 \\
\text { F. } 20.9\end{array}$ & $\begin{array}{l}54,47 \\
45,04 \\
48,94 \\
41,88 \\
54,69 \\
\end{array}$ & 0,585 & $\begin{array}{l}49,55 \\
52,13 \\
44,28 \\
64,38 \\
48,13 \\
\end{array}$ & 0,622 & $\begin{array}{l}49,61 \\
52,26 \\
52,28 \\
54,31 \\
48,42 \\
\end{array}$ & 0,975 & $\begin{array}{l}52,55 \\
52,89 \\
44,56 \\
59,56 \\
47,19 \\
\end{array}$ & 0,747 & $\begin{array}{l}58,45 \\
42,83 \\
46,78 \\
64,06 \\
49,99 \\
\end{array}$ & 0,263 & $\begin{array}{l}50,84 \\
46,43 \\
51,06 \\
63,88 \\
50,27 \\
\end{array}$ & $\begin{array}{l}0,68 \\
8\end{array}$ & $\begin{array}{l}52,89 \\
51,28 \\
44,78 \\
56,88 \\
48,72 \\
\end{array}$ & 0,902 & $\begin{array}{l}52,05 \\
49,28 \\
45,22 \\
59,56 \\
49,92 \\
\end{array}$ & 0,876 & $\begin{array}{l}52,66 \\
47,76 \\
47,22 \\
59,13 \\
50,32 \\
\end{array}$ & 0,883 \\
\hline $\begin{array}{l}\text { Lama } \\
\text { Merawat }\end{array}$ & $\begin{array}{l}0-5 \\
6-10 \\
11-15 \\
>15\end{array}$ & $\begin{array}{l}54,20 \\
38,42 \\
44,72\end{array}$ & 0,070 & $\begin{array}{l}50,27 \\
35,97 \\
43,52\end{array}$ & $\begin{array}{l}\mathbf{0 , 0 0 8} \\
*\end{array}$ & $\begin{array}{l}58,42 \\
57,20 \\
31,78 \\
46,66\end{array}$ & $\begin{array}{l}\mathbf{0 , 0 0 7} \\
*\end{array}$ & $\begin{array}{l}61,07 \\
42,33 \\
38,89 \\
46,00\end{array}$ & $\begin{array}{l}\mathbf{0 , 0 1 6} \\
*\end{array}$ & $\begin{array}{l}54,26 \\
51,20 \\
38,92 \\
52,10\end{array}$ & 0,298 & $\begin{array}{l}61,05 \\
52,17 \\
36,28 \\
42,02 \\
\end{array}$ & $\begin{array}{l}\mathbf{0 , 0 0} \\
7^{*}\end{array}$ & $\begin{array}{l}56,42 \\
\\
54,87 \\
36,42 \\
48,08 \\
\end{array}$ & 0,084 & $\begin{array}{l}55,92 \\
60,80 \\
31,50 \\
48,90\end{array}$ & $\begin{array}{l}\mathbf{0 , 0 1 0} \\
*\end{array}$ & $\begin{array}{l}61,68 \\
53,17 \\
30,19 \\
44,74 \\
\end{array}$ & 0,001* \\
\hline Status & $\begin{array}{l}\text { Menikah } \\
\text { Belum } \\
\text { menikah, } \\
\text { Janda, duda }\end{array}$ & $\begin{array}{l}51,52 \\
44,70\end{array}$ & 0,399 & $\begin{array}{l}50,85 \\
48,50\end{array}$ & 0,769 & $\begin{array}{l}51,64 \\
44,03\end{array}$ & 0,347 & $\begin{array}{l}51,42 \\
45,27\end{array}$ & 0,446 & $\begin{array}{l}50,49 \\
50,53\end{array}$ & 0,996 & $\begin{array}{l}51,92 \\
42,43\end{array}$ & $\begin{array}{l}0,24 \\
1\end{array}$ & $\begin{array}{l}52,76 \\
37,67\end{array}$ & 0,060 & $\begin{array}{l}52,56 \\
38,83\end{array}$ & 0,089 & $\begin{array}{l}52,22 \\
40,73\end{array}$ & 0,157 \\
\hline
\end{tabular}

Keterangan NON PARAMETRIK

*Menunjukan uji beda dengan sajian nilai mean, signifikansi P value $<0,05$ (terdapat perbedaan)

** Menunjukan uji korelasi ( $\mathrm{r}$ hitung< $\mathrm{r}$ table: tidak terdapat hubungan/ $\mathrm{r}$ hitungan < dari 0,20 : tidak ada korelasi. 
Diskusi

Penelitian ini bertujuan untuk mendapatkan gambaran kualitas hidup family caregiver ODS menggunakan alat ukur khusus caregiver yakni Adult Carers Quality of Life (AC-Qol) dan mengetahui aspek-aspek demografi yang mempengaruhi kualitas hidup family caregiver. Ditemukan bahwa kualitas hidup family caregiver ODS tergolong sedang. Kategori tinggi ditunjukkan pada dimensi caring choice. Kategori sedang ditunjukkan oleh dimensi support for caring, caring stress, money matters, personal growth, sense of value, careers satisfaction dan ability to care. Berdasarkan data demografi terdapat hubungan antara variabel kualitas hidup dengan usia dan terdapat perbedaan signifikan pada kualitas hidup family caregiver berdasarkan pendidikan \& lama merawat.

Pada penelitian ini ditemukan mayoritas family caregiver ODS berusia 51-60 tahun (36\%). Hal ini sesuai dengan penelitian yang menyatakan umumnya family caregiver adalah setengah baya dengan status pernikahan mayoritas menikah (85\%) (James et al., 2018)(Sharma et al, 2016). Mayoritas family caregiver ODS adalah perempuan (62\%) dengan status hubungan dengan keluarga yang dirawat adalah anak (63\%). Sama halnya dengan penelitian yang dilakukan oleh (Sharma et al, 2016) yang menyatakan bahwa di seluruh dunia mayoritas wanita biasanya menyediakan perawatan informal bagi anggota keluarga mereka yang mengalami kondisi penyakit medis atau keterbatasan. Selain itu mayoritas family caregiver ODS adalah wanita dikarenakan adanya tuntutan sosial dan budaya untuk berperan sebagai pengasuh.

Mayoritas bersuku Sunda sebesar (94\%) hal ini terjadi dikarenakan RSUD Soreang berlokasi di daerah Kabupaten Bandung yang lingkungan sekitarnya didominasi oleh suku Sunda. Pendidikan mayoritas SD (51\%) dan tidak bekerja (52\%) hal ini dikarenakan mayoritas family caregiver perempuan lebih kecil kemungkinannya untuk memiliki pekerjaan di luar rumah. Peran kerja pada perempuan juga dipandang terpusat di rumah dan mungkin mencerminkan rasa kewajiban keluarga yang lebih besar di antara mereka (Papastavrou, Tsangari, Karayiannis, \& Papacostas, 2011). Mayoritas family caregiver merawat keluarga dengan diagnosis skizofrenia yang tidak tergolongkan (F.20.9).

Peneliti menemukan mayoritas family caregiver tergolong sedang untuk dimensi support for caring(41\%), money matter (51\%), personal growth (40\%), sense of value (40\%), carer satisfaction (53\%). Support for caring adalah sejauh mana family caregiver yang merawat anggota keluarga ODS merasa bahwa mereka merasa berharga, dipahami, dapat berbagi informasi, merasa dihormati dan mendapat dukungan satu sama lain baik oleh anggota keluarga lainya maupun oleh profesional. Hal ini sesuai dengan penelitian yang dilakukan oleh (CaqueoUrízar, Gutiérrez-Maldonado, \& Miranda-Castillo, 2009) bahwa penurunan kualitas hidup pada 
caregiver ODS dapat di kaitkan dengan kurangnya dukungan sosial artinya dalam penelitian ini, semakin tinggi dukungan sosial maka semakin tinggi kualitas hidupnya. Hal ini mungkin mencerminkan kekhasan perbedaan budaya yang mana budaya di Indonesia tinggal bersamaan dengan anggota keluarga lainya, sehingga dapat saling mendukung dan berbagi peran pengasuhan

Money matter adalah bagaimana family caregiver yang merawat anggota keluarga ODS mengatasi situasi keuangan mereka. Hal ini sejalan dengan penelitian (Karanci, 1995) pada 60 caregiver ODS menemukan bahwa biaya keuangan yang harus di tanggung pasien, terutama pada biaya perawatan rumah sakit dan tuntutan lainya seperti rokok adalah beban yang sering dinyatakan caregiver setelah konflik keluarga dan subjective burden. Sehingga dalam penelitian ini money matter tergolong kategori sedang mungkin saja dikarenakan status sosio ekonomi yang memang sudah rendah yang berasal dari staus pekerjaan yang tidak bekerja kemudian disusul dengan family caregiver yang bekerja sebagai buruh serabutan sebelum salah satu anggota keluarga mereka terkena skizoprenia membuat mereka sudah terbiasa berada dalam kondisi keuangan rendah.

Kualitas hidup sedang juga berada pada aspek personal growth (seberapa besar perasaan family caregiver yang merawat anggota keluarga ODS merasa dirinya tumbuh dan berkembang, dan pengalaman positif yang didapat dari keadaan sebagai family caregiver), sense of value (sejauh mana family caregiver yang merawat anggota keluarga ODS merasa dihargai dan dihormati dan adanya hubungan positif antara dirinya dengan orang yang mereka rawat) dan carer satisfaction (sejauh mana family caregiver yang merawat anggota keluarga ODS puas dengan kehidupan dan peran sebagai pengasuh, dan bagaimana perasaan mereka sebagai pengasuh). Kualitas hidup pada aspek personal growth, sense of value dan carer satisfaction mayoritas berada pada aspek sedang. Hal ini mungkin terjadi karena faktor sosio demografis yang mana lebih banyak melibatkan praktek keagamaan. Seperti literatur review yang tentang positive aspects of caregiving in schizophrenia (Kulhara, 2012)menemukan bahwa aspek positif pengasuhan dipengaruhi oleh variabel sosio demografis, klinis dan psikologis. Studi yang dilakukan oleh (Horwitz, Reinhard, \& Howell-White, 1996) pada 66 family caregiver dengan penyakit mental juga menemukan bahwa religiusitas dikaitkan dengan harga diri dan perawatan diri yang lebih baik dan lebih sedikikt mengalami depresi di antara family caregiver.

Kualitas hidup rendah mayoritas family caregiver ODS berada pada aspek ability to care yakni sebanyak $48 \%$. Ability to care adalah sejauh mana family caregiver yang merawat anggota keluarga ODS bisa memberikan perawatan terhadap ODS, bagaimana mereka mengatasi peran, dan bagaimana perasaan mereka tentang kemampuan mereka terhadap caring. Dalam penelitian ini ability to care rendah mungkin saja disebabkan mayoritas family caregiver yang 
mayoritas berusia lanjut usia sehingga kemampuan untuk merawat menjadi berkurang. Hal ini sejalan dalam penelitian yang dilakukan oleh (Shamsaei, Cheraghi, \& Bashirian, 2015) pada 225 family caregiver ODS ditemukan bahwa burden caregiver pada lansia lebih tinggi dibandingkan dengan family caregiver di usia muda. Sehingga dalam penelitian ini dimensi ability to care dapat menjadi faktor menurunkan kualitas hidup. Shamsaei pun mengatakan bahwa ketika caregiver menjadi tua, mereka cemas tentang siapa yang akan merawat anggota keluarga yang sakit di kemudian hari. Family caregiver yang berusia lanjut juga tidak bisa menyediakan perawatan dengan baik kepada anggota keluarga yang sakit. Namun, penemuan ini berbeda dengan penelitian yang di lakukan oleh (Chan, 2011) pada 85 family caregiver mexican American menemukan bahwa family caregiver yang lebih muda memiliki tingkat beban yang lebih tinggi. Perbedaan pada penelitian ini mungkin saja juga terjadi karena faktor budaya Indonesia yang menganggap orang tua sebagai kepala keluarga yang memiliki tanggung jawab mungurus kepala keluarga lainnya. Hal ini sejalan dengan penelitian yang dilakukan oleh (Chien et al., 2007) mengatakan bahwa orang tua memiliki tanggung jawab mengurus aanggota keluarga lainya dan bertanggung jawab atas kondisi kesehatanya.

Kualitas hidup tinggi mayoritas family caregiver ODS berada pada aspek caring choice yakni sebanyak 68\% dan caring stress(51\%). Caring choice adalah sejauh mana family caregiver yang merawat anggota keluarga ODS merasa bahwa mereka memiliki kendali atas kehidupan mereka sendiri, dan dapat memilih melakukan aktivitas lain di luar caring. Dimensi caring choice menjadi tinggi dalam penelitian ini mungkin dikarenakan anggota yang mereka rawat adalah keluarga mereka sendiri, sehingga hal ini mungkin bukan menjadi suatu pilihan tapi jadi keharusan. Seperti dalam penelitian (Settineri, Rizzo, Liotta, \& Mento, 2014) pada 294 caregiver dengan (142 caregiver dengan gangguan fisik, 88 caregiver dengan gangguan mental, keduanya 64) menemukan bahwa motivasi perawatan yang dilakukan oleh family caregiver sebanyak 76,2\% mengatakan karena rasa kasih sayang, 11,6\% tugas dan tanggung jawab dan sebanyak 4,8\% disebabkan karena tidak ada pilihan. Sehingga dalam penelitian ini caring choice dapat membantu meningkatkan kualitas hidup family caregiver.

Caring stres yakni tekanan mental fisik dari caring, seperti kelelahan dan depresi. kualitas hidup pada domain caring stress dalam penelitian ini tinggi. Hal ini berbeda dengan penelitian yang dilakukan oleh (Settineri et al., 2014) pada 294 caregiver dengan (142 caregiver dengan gangguan fisik, 88 caregiver dengan gangguan mental, keduanya 64) yang menemukan bahwa family caregiver yang merawat ODS menunjukan beban emosional yang lebih besar dan lebih buruk dalam kualitas hidupnya. Hal ini berbeda mungkin saja dikarenakan mayoritas Pendidikan family caregiver yang berada pada tingkatan SD membuat penghayatan mereka tentang perawatan tidak seberat family caregiver dengan pendidikan lebih tinggi. Hal ini sesuai 
dengan penelitian yang dilakukan oleh (Zahid \& Ohaeri, 2010) pada 121 family caregiver ODS menemukan bahwa beban tinggi dalam perawatan berhubungan dengan tingkatan Pendidikan. (Shamsaei et al., 2015) juga mengatakan bahwa ada kemungkinan tingkat pendidikan yang lebih tinggi bertanggung jawab untuk persepsi yang lebih besar tentang kompleksitas terlibat dalam pemberian perawatan.

Peneliti menemukan rata -rata family caregiver yang tergolong memiliki kualitas hidup rendah memiliki dimensi rendah pada dimensi support for caring, caring stress, money maters, personal growth, sense of value ability to care career satisfaction dan terdiri dari caring choice yang sedang. Pada family caregiver yang tergolong memiliki kualitas hidup sedang terdiri dari dimensi sedang di seluruh dimensi nya dan family caregiver yang tergolong memiliki kualitas hidup tinggi terdiri dari dimensi sedang pada support for caring dan money matters, sedangkan pada dimensi caring choice, caring stress, personal growth, sense of value ability to care career satisfaction.

Untuk data demografi, terlihat dalam tabel 5. bahwa besaran nilai korelasi antara usia antara responden adalah $r=-0,390$ dengan P-value 0,000 artinya usia memiliki korelasi yang signifikan dengan kualitas hidup. Nilai koefisien bernilai negatif bernakna semakin tua usia family caregiver mengakibatkan semakin rendahnya kualitas hidup atau sebaliknya.

Pada penelitian ini menemukan bahwa terdapat perbedaan yang signifikan terhadap kategori Pendidikan dan lamanya merawat. Hal ini selaras dengan penelitian yang dilakukan oleh (Zahid \& Ohaeri, 2010) pada 121 caregiver di Arab yang menemukan bahwa indeks beban obyektif tidak terkait secara signifikan dengan jenis kelamin, usia, perkawinan status, pengaturan hidup, pendapatan keluarga, melainkan dengan tingkat pendidikan. Begitupula penelitian yang dilakukan pada 96 family caregiver yang menemukan bahwa tingkat pendidikan family caregiver adalah burden prediktor terbaik. Lamanya merawat berpengaruh pada kualitas hidup caregiver ODS, pada penelitian ini ditemukan bahwa rentang perawatan yang lebih sebentar (0-5 tahun) mengakibatkan kualitas hidup family caregiver yang lebih tinggi. Hal ini sejalan dengan penelitian yang dilakukan oleh (Caqueo-Urízar et al., 2009) bahwa lamanya penyakit orang yang dirawat menjadi mempengaruhi tingkat beban yang di alami.

Untuk uji beda pada per dimensi menunjukan hasil bahwa terdapat berbedaan yang signifikan antara dimensi caring stress, money matter, carer statisfaction dengan kategori pendidikan artinya semakin tinggi tingkat pendidikan family caregiver maka semakin tinggi tingkat kualitas hidup pada dimensi caring stress, money matter, carer statisfaction. Selanjutnya terdapat perbedaan yang signifikan antara dimensi caring choice, caring stress, money matter, ability to care dan carer satisfaction dengan kategori lamanya merawat. 


\section{Simpulan}

Orang dengan skizofrenia (ODS) membutuhkan orang lain dalam menjalankan fungsi sehari-harinya. Umumnya hal ini dilakukan oleh anggota keluarganya: family caregiver. Secara umum kualitas hidup family caregiver pasien ODS tergolong sedang. Hanya dimensi caring choice yang tergolong tinggi. Sedangkan kategori sedang ditunjukkan oleh dimensi support for caring, caring stress, money matters, personal growth, sense of value, careers satisfaction dan ability to care.

Berdasarkan data demografi terdapat hubungan antara variabel kualitas hidup dengan usia yang artinya semakin tua usia family caregiver mengakibatkan semakin rendahnya kualitas hidup atau sebaliknya. Terdapat perbedaan signifikan pada kualitas hidup family caregiver berdasarkan kategori pendidikan dan lama merawat. Perbedaan signifikan pada kategori pendidikan artinya family caregiver yang memiliki tingkat pendidikan lebih tinggi memiliki akses informasi lebih luas dan memiliki sumber daya komunitas yang dapat membantu merawat. Perbedaan signifikan pada kategori lama merawat yang artinya semakin lama durasi merawat semakin rendah kualitas hidup family caregiver .

\section{Saran}

Berdasarkan kesimpulan dari hasil dan pembahasan penelitian ini, terdapat beberapa saran yang dapat diaplikasikan oleh bidang-bidang yang berkaitan, diantaranya (1) Family caregiver ODS perlu meningkatkan pengetahuan dalam menghadapi situasi ODS kambuh serta mengelola stres yang dirasakan dengan mengenali batasan kemampuan dalam perawatan (2) RSUD sebaiknya melakukan intervensi untuk meningkatkan kualitas hidup family caregiver yakni melakukan pendampingan rutin kepada family caregiver berupa Pusat Informasi mengenai perawatan ODS atau berupa brosur yang berisikan panduan perawatan ODS.

\section{Kepustakaan}

American Psychiatric Association. (2013). Diagnostic and statistical manual of mental disorders fifth edition. In Washington: American Psychiatric Publishing.

Brand, C., Brand, C., Barry, L., \& Gallagher, S. (2014). Social support mediates the association between benefit finding and quality of life in caregivers. (October). https://doi.org/10.1177/1359105314547244

Caqueo-Urízar, A., Gutiérrez-Maldonado, J., Ferrer-García, M., Pẽaloza-Salazar, C., RichardsAraya, D., \& Cuadra-Peralta, A. (2011). Attitudes and burden in relatives of patients with schizophrenia in a middle income country. BMC Family Practice, 12(1), 101. https://doi.org/10.1186/1471-2296-12-101

Caqueo-Urízar, A., Gutiérrez-Maldonado, J., \& Miranda-Castillo, C. (2009). Quality of life in caregivers of patients with schizophrenia: A literature review. Health and Quality of Life Outcomes, 7, 84. https://doi.org/10.1186/1477-7525-7-84 
Chan, S. W. (2011). Global Perspective of Burden of Family Caregivers for Persons With Schizophrenia. Archives of Psychiatric Nursing, 25(5), 339-349. https://doi.org/10.1016/j.apnu.2011.03.008

Chien, W.-T., Chan, S. W., \& Morrissey, J. (2007). The perceived burden among Chinese family caregivers of people with schizophrenia. Journal of Clinical Nursing, O(0), 080228010643213-??? https://doi.org/10.1111/j.1365-2702.2005.01501.x

Horwitz, A. V., Reinhard, S. C., \& Howell-White, S. (1996). Caregiving as Reciprocal Exchange in Families with Seriously Mentally Ill Members. Journal of Health and Social Behavior, 37(2), 149-162. https://doi.org/10.2307/2137270

James, S. L., Abate, D., Abate, K. H., Abay, S. M., Abbafati, C., Abbasi, N., ... Murray, C. J. L. (2018). Global, regional, and national incidence, prevalence, and years lived with disability for 354 Diseases and Injuries for 195 countries and territories, 1990-2017: A systematic analysis for the Global Burden of Disease Study 2017. The Lancet, 392(10159), 1789-1858. https://doi.org/10.1016/S0140-6736(18)32279-7

Joseph, S., \& Becker, S. (2012). Adult carers quality of life questionnaire ( AC-QoL ): Development of an evidence-based tool Mental Health Review Journal Emerald Article : Adult carers quality of life questionnaire ( $A C$-QoL ): development of an evidence-based tool Adult carers quality $o$. (June). https://doi.org/10.1108/13619321211270380

Karanci, A. N. (1995). Caregivers of Turkish schizophrenic patients: causal attributions, burdens and attitudes to help from the health professionals. Social Psychiatry and Psychiatric Epidemiology, 30(6), 261-268. https://doi.org/10.1007/BF00805792

Katschnig, H. (2000). Schizophrenia and quality of life. 102, 33-37.

Kementerian Kesehatan RI Badan Penelitian dan Pengembangan. (2018). Hasil Utama Riset Kesehatan Dasar. Kementrian Kesehatan Republik Indonesia, 1-100. Retrieved from http://www.depkes.go.id/resources/download/info-terkini/hasil-riskesdas-2018.pdf

Kulhara, P. (2012). Positive aspects of caregiving in schizophrenia: A review. World Journal of Psychiatry, 2(3), 43. https://doi.org/10.5498/wjp.v2.i3.43

Papastavrou, E., Tsangari, H., Karayiannis, G., \& Papacostas, S. (2011). Caring and coping : The dementia caregivers Caring and coping: The dementia caregivers. (August). https://doi.org/10.1080/13607863.2011.562178

Settineri, S., Rizzo, A., Liotta, M., \& Mento, C. (2014). Caregiver's burden and quality of life: Caring for physical and mental illness. International Journal of Psychological Research, 7(1), 30-39. https://doi.org/10.21500/20112084.665

Shamsaei, F., Cheraghi, F., \& Bashirian, S. (2015). Burden on family caregivers caring for patients with schizophrenia. Iranian Journal of Psychiatry, 10(4), 239-245.

Sulistyorini, N. (2013). Hubungan Pengetahuan Tentang Gangguan Jiwa terhadap Sikap Masyarakat kepada Penderita Gangguan Jiwa di Wilayah Kerja Puskesmas Colomadu 1. Program Studi Ilmu Keperawatan Fakultas Ilmu Kesehatan Universitas Muhammadiyah Surakarta, 1, 1-15.

van Os, J., \& Kapur, S. (2009). Schizophrenia. The Lancet, 374(9690), 635-645. https://doi.org/10.1016/S0140-6736(09)60995-8 
Zahid, M. A., \& Ohaeri, J. U. (2010). Relationship of family caregiver burden with quality of care and psychopathology in a sample of Arab subjects with schizophrenia. BMC Psychiatry, 10. https://doi.org/10.1186/1471-244X-10-71 